УДК 343.985

DOI https://doi.org/10.32844/2618-1258.2019.3-2.22

КОЛОДІНА А.С.

\title{
ЕВРИСТИЧНИЙ ПІДХІД ДО ПОБУДОВИ МЕТОДИКИ РОЗСЛІДУВАННЯ: АКТУАЛЬНІ ПИТАННЯ
}

\begin{abstract}
Формування окремих методик розслідування злочинів пов'язане 3 низкою питань, зокрема й теоретико-методологічного характеру. Серед таких питань нерідко можна зустріти дослідження, що стосується технологічного підходу до побудови методики розслідування злочинів. Застосування технологічного підходу в процесі розслідування злочинів $\epsilon$ наслідком теперішнього прогресу технологізації, а стрімкий розвиток теорії криміналістичної технології - актуальним у галузі криміналістики. Використання поняття «технологічний підхід» під час побудови окремих криміналістичних методик розслідування дозволяє не тільки синтезувати теоретичні знання, але й побудувати технології здійснення слідчих дій у практичній діяльності.
\end{abstract}

Евристичний підхід до побудови криміналістичної методики, у свою чергу, передбачає: 1) побудову криміналістичної методики суб'єктом розслідування в разі iï відсутності; 2) застосовування криміналістичних алгоритмів та програм, що доцільно розробляти в методиках розслідування окремих видів злочинів для успішного й ефективного виконання завдань. Евристичний підхід проявляється тоді, коли слідчий за відсутності належної методики для розслідування самостійно відшукує методи та засоби виконання поставлених завдань, ураховуючи індивідуальні особливості розслідуваної події, а також застосовує творчий хід мислення, який не збігається з типовими рекомендаціями, що призводить до пошуку іншого, нетрадиційного рішення. При цьому потрібно зазначити, що використання евристичного підходу до побудови криміналістичної методики потребує від слідчого не лише наявності значного практичного досвіду, а й творчого потенціалу, адже евристичне мислення - це вищий рівень інтелектуальної організації особистості.

У статті здійснено спробу виділення понять криміналістичної евристики, евристичних методів, питань алгоритмізації та програмування, особливо в контексті криміналістичної методики, обгрунтовано застосування евристичного підходу під час побудови останньої, а також виокремлено систему принципів евристичної діяльності слідчого щодо формування методик розслідування у двох ситуаціях: 1) розроблена криміналістична методика не відповідає потребам практики та потребує суттєвої адаптації до сучасних умов; 2) криміналістична методика розслідування конкретного виду злочину відсутня.

Ключові слова: методика розслідування злочинів, евристика, евристичний підхід, слідча діяльність, евристична діяльність, криміналістична евристика, евристичний метод, алгоритм, програмування.

The formation of crime investigation techniques involves a number of issues, including theoretical and methodological issues. Among such issues, one can often find research on the technological approach to crime scene investigation. The use of a technological approach in the process of crime investigation is a consequence of the current technological advancement, and the rapid development of forensic technology theory is relevant in the field of forensic science. The use of the concept of "technological approach" in the construction of individual forensic investigative techniques, allows not only to synthesize theoretical knowledge, but also to build technologies for the implementation of investigative actions in practice.

( ) КОЛОДІНА А.С. - кандидат юридичних наук, доцент, доцент кафедри криміналістики (Національний університет «Одеська юридична академія») 
A heuristic approach to the construction of forensic methodology involves: 1) the construction of the forensic methodology by the subject of the investigation (in the absence thereof); 2) the application of forensic algorithms and programs, which should be developed in the methods of investigation of certain types of crimes for successful and effective execution of tasks. The heuristic approach is manifested when the investigator (in the absence of a proper methodology for investigation) independently finds methods and means of performing the assigned tasks. The investigator takes into account the individual characteristics of the event being investigated, as well as applies creative thinking that does not conform to the typical recommendations, which leads to the search for another, unconventional solution. It should be noted that the use of a heuristic approach to the construction of forensic methodology requires not only significant practical experience but also the creative potential for the investigator. Heuristic thinking is the highest level of the intellectual organization of the individual.

The article attempts to distinguish the concepts of forensic heuristics, heuristic methods, algorithmic and programming issues, especially in the context of forensic methodology, substantiates the use of heuristic approach in constructing the latter, and also distinguishes the system of principles of heuristic activity of investigator in the formation of methods forensic methodology does not meet the needs of practice and requires a significant adaptation to modern conditions; 2) there is no forensic methodology for investigating a specific type of crime.

Key words: crime investigation methodology, heuristics, heuristic approach, investigative activity, heuristic activity, forensic heuristics, heuristic method, algorithm, programming.

Вступ. Розслідування злочинів за своєю сутністю $є$ пізнавальним процесом, адже складність завдань, які постають перед слідчим, потребують застосування різноманітних шляхів та засобів виконання розумових операцій. У вирішенні цих питань особливу роль відіграють: програмування, алгоритмізація, застосування криміналістичної методики та творчий елемент до побудови нової криміналістичної методики, якщо вона відсутня. Дослідження даних понять у сукупності зумовлюється, перш за все, виходячи із завдань, які виконуються в ході розслідування, як уважає Д.І. Сулейманов: 1) творчим, нестандартним підходом до пошуку шляхів і способів рішення, невідомих раніше; 2) і таким, що розв'язується типово або потребує вибору придатного способу рішення з числа відомих типових способів і адаптації його до конкретного випадку [1, с. 35].

У криміналістичній науці підкреслювалась необхідність поєднання евристичного та алгоритмічного підходу, саме тому слід погодитись із позицією Л.Д. Самигіна і А. Форкера, що евристичний підхід необхідно поєднувати з алгоритмічним, оскільки в різних ситуаціях один із них відіграє вирішальну роль, але вони завжди доповнюють один одного [2, с. 123], тому вважаємо за потрібне досліджувати їх комплексно. Розвиваючи цю тезу, необхідно також наголосити, що застосування цих підходів відбуватиметься на різних стадіях інтелектуальної роботи слідчого. Евристичний підхід використовується для формування первинної теоретичної моделі методики розслідування злочину, зокрема визначення іiі структури обов'язкових елементів. У свою чергу, алгоритмічний підхід слугуватиме формою організації впровадження створеної методики в конкретну предметну діяльність слідчого.

В.В. Тіщенко підкреслив, що слідчий сам повинен обрати оптимальну систему діяльності з розкриття і розслідування злочинів, вбачаючи в цьому виявлення творчого характеру слідчої діяльності [229, с. 105].

Останнім часом спостерігається бажання вчених змінити напрям наукового пошуку: від «книжкових методик» до побудови алгоритмів і програм дій слідчого відповідно до типових ситуацій $[3$, с. 191]. Ще Р.С. Бєлкін піддавав критиці «книжкові методики» і наголошував, що рядовий слідчий, який не має достатньо професійного досвіду, за умов дефіциту часу та в екстремальній ситуації не в змозі відтворити в пам'яті десятки сторінок цієї методики як оперативного посібника до необхідних дій [4, с. 127], тому актуальним є створення алгоритмів та програм, які безумовно полегшать процес розслідування.

Отже, сьогодні можна говорити про існування традиційної описової форми викладення криміналістичних методичних рекомендацій (так званої «книжкової методики») і новаторської у вигляді відповідних алгоритмів та програм [5, с. 191], серед яких належної уваги та з'ясування 
потребує творчий (евристичний) підхід як у діяльності слідчого, так і під час побудови криміналістичної методики розслідування злочинів зокрема.

Гносеологічним підгрунтям для реалізації евристичного підходу в слідчій діяльності можна вважати дефіцит, недостатність криміналістично значущої інформації для розв'язання пізнавальних задач, тому є необхідність вести мову про виконання цих завдань евристичними шляхами.

Стан дослідження теми. На застосування евристичного підходу в діяльності слідчого звертають увагу такі вчені, як І.Є. Биховський, Н.Б. Водянова, Г.О. Зорін, В.А. Журавель, М.І. Єникеєв, Є.П. Іщенко, В.О. Коновалова, Л.Д. Самигін, В.Л. Синчук, Л.Я. Соя-Серко, Д.І. Сулейманов, В.А. Терехов, В.В. Тіщенко, А. Форкер, Б.В. Щур та ін.

Виконання пошукових завдань слідчого пов'язано з активним пошуком нових засобів отримання недостатньої інформації, де пізнавальна діяльність слідчого розвивається за психологічними закономірностями виконання складних нестандартних завдань [6, с. 124]. Тому дефіцит криміналістично значущої інформації потребує від слідчого саме евристичних рішень.

Постановка завдання. У зв'язку з вищевикладеним потрібно з'ясувати, що таке евристика взагалі, дати поняття криміналістичної евристики, зрозуміти, в чому полягає евристичний підхід під час побудови криміналістичної методики розслідування злочинів, а також як співвідносяться між собою програма і алгоритм та яке місце серед них займає творчий (евристичний) підхід до побудови методики розслідування.

Результати дослідження. Евристика (грец. heurisko - знаходжу, відкриваю) - це сукупність дослідницьких методів, спрямованих на відкриття, пізнання нового, раніше не відомого [7, с. 225].

Є.П. Іщенко та Н.Б. Водянова під евристичною діяльністю пропонують розуміти сукупність притаманних людині механізмів, за допомогою яких розроблюються процедури, які направлені на виконання творчих завдань, прийняття рішень в умовах нестандартних ситуацій [8, с. 109]. Дане визначення не викликає заперечень, але потребує певного доповнення. Постає запитання: що слід розуміти під «сукупністю притаманних людині механізмів»? На наш погляд, може йтися про досвід, інтуїцію, логічне мислення, рефлекторні фактори при виконанні нетипових завдань у будь-якій діяльності.

Є.П. Іщенко під криміналістичною евристикою розуміє сукупність знань про творчі способи виконання складних слідчих завдань, які виникають у проблемних ситуаціях, що відрізняються недостатністю вихідної інформації. Використовуючи ці знання, слідчий не йде шляхом повного перебирання всіх варіантів виконання завдань, а оптимізує пошуки, опрацьовуючи лише деякі з варіантів [9, с. 118].

Г.А. Зорін уважає, що криміналістична евристика - це відображення індивідуальної методології, оскільки поза інтелектуальної діяльності слідчого вона не існує [10].

На наш погляд, криміналістичною евристикою можна вважати інтелектуальну діяльність слідчого, яка полягає в застосуванні перш за все творчого підходу, системи методів, прийомів та способів для виконання нетипових завдань, які стоять під час розслідування кожного індивідуального випадку.

I.С. Биховський завжди відстоював евристичний підхід у діяльності з розслідування та вказував, що «слідство завжди було, $є$ і буде не тільки комплексом наукових положень і рекомендацій, але й мистецтвом знаходження істини» [11, с. 67].

Л.Я. Соя-Серко вважає, що здібності до евристичної (перетворювальної, пошукової) обробки інформації мають місце саме тоді, коли логічне мислення перетинається із творчим, тому що для творчого мислення наявних знань недостатньо, а логічне мислення неможливе через відсутність необхідних для цього даних: «Відсутні знання слідчий отримує завдяки творчій фантазії, уяві, найрізноманітнішим комбінаціям, що дозволяє виявити зв'язки і залежності між відомим і ще невідомим, заповнити прогалини у вихідних даних» [12, с. 42].

Логіка міркувань наштовхує на запитання: у чому все ж таки полягає евристичний підхід та яким чином він застосовується під час побудови криміналістичної методики розслідування злочинів?

Формування будь-якої криміналістичної методики розслідування особою, яка пізнає кримінально релевантну подію конкретного злочину, має базуватись на методичних рекомендаціях, основоположних принципах, які розроблені та обгрунтовані наукою. Слідчий повинен адаптувати їх до умов конкретного провадження, виділити ті особливості в розслідуванні злочину, які визначаються індивідуальними ознаками, обставинами злочину, що спричиняє творчий пошук засобів та методів виконання виникаючих завдань. 
На наш погляд, евристичний підхід проявляється саме тоді, коли слідчий за відсутності належної методики для розслідування самостійно відшукує методи та засоби виконання поставлених завдань, ураховуючи індивідуальні особливості розслідуваної події, а також застосовує творчий хід мислення, який не збігається з типовими рекомендаціями, що призводить до пошуку іншого, нетрадиційного рішення.

На підставі вищезазначеного постає запитання: на чому грунтується евристичний підхід? Також виникає необхідність виділення методів евристичного підходу до побудови методики розслідування.

Вважаємо, що евристичний підхід грунтується на базі даних, досвіді роботи у сфері слідчої діяльності, логічному мисленні, інтуїції слідчого та інших професійних якостях, набутих у ході здійснення цієї діяльності.

Узагалі перше вчення про евристичні методи було розроблено та введено в практику Сократом. Як філософ він ставив собі мету викладати не готову систему, а метод, із застосуванням якого можна розробляти системи. Його цікавила не структура (будова системи), а рекомендації про те, як діяти при її побудові. При цьому він вважав за краще бесіду, дискусію, у ході якої сприяв своїм співрозмовникам у міркуваннях [10].

Евристика - це особлива галузь інтелектуальної діяльності, що відображає суму методів, прийомів і способів, якими володіє слідчий під час вирішення конкретної задачі, винаходу методів розслідування злочинів [10].

Г.А. Зорін під методами розуміє гармонійну систему прийомів, що забезпечують розширення пошукового та аналітичного «кола» слідчого. Це стиль професійних дій, що визначає можливості та обмеження [10].

Метод - це форма творчого пошуку, зумовлена системою цілей, які ставлять перед слідчим поточна і перспективна ситуації.

Ю.П. Аленін звертав увагу на те, що під час розв'язання нестандартних задач використовуються такі методи евристичного слідчого пізнання, як інтерполяція, екстраполяція, інтерпретація та розумове моделювання, де загальним методом вирішення пізнавальних задач у ході розслідування є інформаційне моделювання [13, с. 57].

На нашу думку, евристичні методи можна розглядати як: спеціальні методи аналізу, що базуються на використанні досвіду, інтуїції фахівця та його творчого мислення (1); способи досягнення поставленої мети для виконання конкретного завдання, що розглядаються як сукупність прийомів теоретичного або практичного пізнання (2).

Аналізуючи окремі евристичні методи, необхідно надати характеристику найважливішим, які є обов’язковою умовою формування криміналістичної методики слідчим.

Так, на нашу думку, ключовим евристичним методом виступає метод моделювання. Необхідність використання моделювання в реалізації евристичного підходу значною мірою зумовлюється початковою слідчою ситуацією розслідування злочину за відсутності конкретної методики, коли існує необхідність опосередкованого пізнання елементів події злочину та перехід від рівня аналізу емпіричних даних до абстрактно-теоретичних узагальнень.

Так, результатом використання методу моделювання є створення конкретної моделі, яка в контексті використання евристичного підходу характеризуватиметься такими ознаками: виступає єднальним елементом між подією і їі розумовим сприйняттям слідчим; виступає у формі ідеальної системи; має ймовірний характер; може бути одночасно ретроспективною $\mathrm{i}$ перспективною.

Продовжуючи аналіз методів евристичного підходу в роботі слідчого, необхідно звернути увагу на напрацювання інших галузей наукового знання, які інтенсивно проникають у криміналістику. Як окрему групу методів можливо виокремити методи психологічної активаиії мислення, які спрямовані на усунення перешкод для винахідницьких рішень та нових ідей і забезпечують всебічне вивчення об'єкта пізнання. У контексті евристичної діяльності слідчого до таких методів можна віднести: мозковий штурм - один із найвідоміших методів колективного пошуку нестандартних рішень. Водночас необхідно зазначити, що його використання передбачає наявність групи суб'єктів, і тому слідчому необхідно залучити до цієї діяльності працівників оперативних підрозділів, експертів-криміналістів та інших осіб, які здатні допомогти в пізнанні конкретної події злочину; метод синектики, який передбачає використання асоціативних зв'язків і дозволяє слідчому активізувати для прийняття евристичних рішень раніше напрацьований професійний та життєвий досвід. При цьому під час використання даного методу характерним $\epsilon$ застосування різноманітних форм аналогії. 
Наступною групою евристичних методів є методи систематизованого пошуку, серед яких окремої уваги заслуговують: функціональний аналіз, який дозволяє слідчому абстрагуватись від конкретної події загалом і сконцентрувати свою увагу на функціях окремих елементів системи, наприклад, аналізуючи послідовні дії злочинця, визначити конкретне функціональне призначення кожної з них і тим самим узагальнити теоретичну модель події злочину; метод багаторазової послідовної класифікації, який забезпечує зниження важливості окремих елементів чи подій шляхом їх відфільтровування.

Поряд із наведеними методами під час використання евристичного підходу слідчим, безумовно, використовуються й традиційні методи пізнання дійсності (зокрема індукція, дедукція, синтез, аналіз тощо), але оскільки їх сутність детально описана у філософських джерелах, ми не зосереджуємося на них.

Необхідно звернути увагу, що евристичні методи слідчої діяльності не мають заздалегідь запрограмованих та чітко сформованих етапів реалізації. Методи формуються слідчим щоразу стосовно індивідуальних умов конкретної слідчої ситуації [14, с. 148]. Евристичні методи значно скорочують час розв'язання задач, навіть таких, які піддаються алгоритмуванню, оскільки виключають повний перебір можливих альтернатив, однак результати, які одержуються в цьому випадку, не завжди є повними, однозначними і правильними, тобто оптимальними [15, с. 754].

Стосовно слідчої роботи головне завдання евристичних методів - викликати нові асоціації, нові блоки інформації про різні зв’язки з вихідних даних проблемної кримінальної ситуації, розслідування якої заходить у «глухий кут», не спричиняє перспективи на встановлення істини [10].

Евристика, застосовувана під час розкриття злочинів, акумулює в собі потенціал творчих можливостей слідчого, оскільки евристичні методи опосередковують процеси нагромадження, відбору, обробки, цілеспрямованого аналізу криміналістичної інформації. Особливо широко евристика використовується під час побудови версій, де вихідні дані багаторазово і під різними кутами видозмінюються, комбінуються і перетворюються, щоб пояснити причини і процеси досліджуваної слідчим події [10].

Разом із тим слід зауважити, що в діяльності слідчого під час розслідування злочинів, крім вирішення розумових задач із використанням творчого підходу до ситуації, прийнято виділяти використання алгоритмів. Тому рекомендації науки криміналістики повинні поєднуватись 3 евристикою та точними правилами - алгоритмами [16, с. 167-170].

Застосування криміналістичних алгоритмів, або програм, які можливо розробляти в методиках розслідування окремих видів злочинів, зазвичай відбувається в ході розслідування при однотипних (шаблонних) справах або таких, що потребують вибору рішення зі здебільшого вже відомих способів, вирішуються програмними та алгоритмічними шляхами, на чому хотілось би також зосередити увагу. Адже застосування в ході розслідування програм та алгоритмів сприяє ефективності, економії часу та оптимізації в інтелектуальній діяльності слідчого.

Намагання науковців надати практиці передові рекомендації щодо підвищення ефективності слідчої діяльності і такого іiї аспекту, як планування, закономірно привернули їхню увагу до розроблення і запровадження криміналістичних алгоритмів та програм розслідування [17, с. 50; 18, с. 109].

Актуальність написання статті та висвітлення питань алгоритмізації та програмування, особливо в контексті криміналістичної методики, зумовлена тим, що, як влучно підкреслено О.В. Синчуком, однією із причин необхідності запровадження програмування та алгоритмізації в процес розслідування злочинів слід вважати те, що існуюча форма викладення змісту окремих криміналістичних методик є громіздкою, не дає змогу слідчому, який не має відповідного професійного досвіду, в умовах дефіциту часу й екстремальної ситуації відтворити в пам'яті десятки сторінок цих методик як оперативного посібника до дій [19, с. 162].

У криміналістичній літературі нерідко можна зустріти ототожнення понять «алгоритм» $\mathrm{i}$ «програма», які схожі за змістом, але мають різне семантичне значення. Наприклад, I.А. Возгрін не розмежовує поняття криміналістичного алгоритму і програми розслідування [20, с. 205].

Так, під алгоритмом найчастіше розуміють систему операцій, що здійснюються за чітко визначеними правилами і після послідовного їхнього виконання призводять до розв'язання запропонованої задачі [21, с. 23], або програму, що зумовлює спосіб поведінки і являє собою систему правил для ефективного виконання завдань [22, с. 18]. Тому, напевно, в літературі можна нерідко зустріти ототожнення цих понять, які насамперед мають різне змістове навантаження.

O.C. Шаталов під криміналістичним алгоритмом пропонує розуміти науково обгрунтований припис щодо виконання в завданому порядку системи послідовних операцій, рекомендованих слідчому, для розв’язання задач певного типу [23, с. 35$]$. 
В.А. Журавель, розглядаючи криміналістичні алгоритми, указує, що необхідно враховувати те, що їхня побудова відбувається на основі повторюваності явищ, наявності в них внутрішніх закономірностей, а саме змінюваності і відносної сталості [5, с. 195].

Програма (грец. programma - розпорядження, оголошення) - план діяльності; послідовний перелік дій до виконання; в кібернетиці - докладний план дії обчислювальної машини, що складається з послідовних команд (інструкцій), за якими виконується весь процес [7, с. 591].

Г.А. Густов розглядає програму розслідування як систему рекомендацій, що включають опис засобів, прийомів, методів їхнього вирішення, метою якої є надання допомоги працівникам правоохоронних органів в отриманні нових знань у кримінальній справі та організації ії розслідування [24, с. 18$]$.

Програма розслідування, на думку В.А. Журавля, може і повинна містити як формалізовані, тобто жорстко детерміновані системи дій, так і неформалізовні криміналістичні знання, наприклад, у вигляді певних рекомендацій щодо з'ясування ситуацій вибору засобів розв'язання типових задач [5, с. 195].

Програмування - це метод раціоналізації розслідування, який полягає в специфічній організації та забезпеченості слідчого криміналістичною інформацією, яка складає основу його криміналістичних знань [10, с. 145].

Із вищевказаного постає закономірне запитання: яким чином будується алгоритм та програма під час розслідування, на основі чого вибудовується система дій до обов'язкового їх виконання? У літературі стосовно цього питання пропонуються підходи до побудови алгоритмів і програм, на які хотілось би звернути увагу.

Для побудови алгоритму О.М. Асташкіна та М.О. Марочкін виділяють такі етапи: 1) аналіз інформації про злочини одного виду, на підставі яких будуватимуться алгоритми їх розслідування; 2) виділення типових слідчих ситуацій, що виникають на різних етапах розслідування (початковому, наступному, заключному); 3) визначення завдань розслідування, що характерні для кожної типової слідчої ситуації; 4) визначення засобів виконання типових завдань розслідування відповідно до виду алгоритму; 5) визначення методу побудови алгоритму; 6) побудова алгоритму; 7) експериментальна перевірка та оперативна корекція побудови типових алгоритмів до умов типової слідчої ситуації; 8) упровадження створених криміналістичних алгоритмів і програм у практику розслідування злочинів як на паперовому носії, так і в електронному варіанті з використанням ЕОМ [9, с. 14-19].

Стосовно елементів загальної програми розслідування М.О. Селіванов виокремлює такі: 1) визначення мети; 2) з'ясування переліку засобів досягнення цієї мети; 3) формування найкращої послідовності дій для досягнення мети [207, с. 140].

На наш погляд, «алгоритм» і «програму» варто розглядати як взаємопов’язані, але відносно самостійні поняття. Також підтримуємо думку вчених, які вважають, що розглядувані поняття не збігаються, але близькі і по суті об'єднуються на одному етапі підготовки до виконання тих завдань, які існують у слідчій тактиці та методиці розслідування злочинів [11, с. 194].

На підставі викладених суджень вважаємо, що криміналістичний алгоритм - це сукупність взаємопов'язаних, залежних від слідчої ситуації слідчих та інших процесуальних дій, які мають єдину мету та підлягають виконанню у вигляді послідовних правил.

Програма розслідування - більш узагальнене поняття, яке охоплює сукупність алгоритмів, тобто послідовність тих чи інших дій (системи дій), постановку завдань і цілей та опис їх виконання і досягнення, що має рекомендаційний характер.

На підставі вищевикладеного вважаємо, що програма та алгоритм, побудовані слідчим, не можуть бути вичерпними, оскільки слідчий у своїй пізнавальній діяльності зіштовхується 3 великою кількістю різноманітних ситуацій, кожна з яких потребує індивідуального (творчого) підходу.

Так, евристичний підхід під час побудови методики розслідування злочинів дозволяє розглядати його як складний, творчий, пізнавальний процес, де використання алгоритму є допоміжною складовою частиною цього процесу, а програмування - процесом раціоналізації розслідування, що містить і алгоритмізацію, і застосування евристики.

Отже, на підставі вищевикладеного можемо стверджувати, що під час побудови криміналістичної методики (відсутності належної), якщо слідчий стикається з нетиповою ситуацією, яку необхідно негайно вирішити, він завжди використовує методи, систему методів для оптимального розслідування злочинів, тобто творчий (евристичний) підхід. При цьому, обираючи метод, слідчий має можливість використання традиційного, стандартизованого варіанту, тобто логічного 
методу, але й у цьому випадку логічний метод перетворюється, адаптується до реальних умов. Це дозволяє вважати, що практично кожен метод, який використовується слідчим, тією чи іншою мірою є евристичним [10]. Коли ж ситуація є шаблонною (типовою), слідчий у своїй діяльності користується алгоритмами, програмами.

Виокремлюючи безпосередньо принципи формування криміналістичних методик, необхідно звернути увагу, що їхня система, на нашу думку, залежить від суб'єкта формування та ситуації, яка детермінує формування методики. Щодо суб’єктів формування, то, на наш погляд, необхідно виокремити вчених та слідчих. При цьому можна виокремити дві ситуації, які детермінують необхідність розроблення методики розслідування: 1) розроблена криміналістична методика не відповідає потребам практики та потребує суттєвої адаптації до сучасних умов (наприклад, методика розслідування злочинів корупційної спрямованості у світлі постійних змін антикорупційного законодавства); 2) криміналістична методика розслідування конкретного виду злочину відсутня.

Висновки. Так, аналізуючи особливості евристичної діяльності слідчого щодо формування методик розслідування, можна виокремити систему принципів для кожної з наведених ситуацій.

У випадку, якщо наявна криміналістична методика не відповідає потребам практики, то слідчий, зважаючи на зміни в законодавстві та власний досвід, із використанням творчого підходу повинен максимально адаптувати наявну методику до конкретних умов, що фактично може призвести до формування на базі існуючої принципово нової методики розслідування злочинів конкретного виду. У даному випадку, на нашу думку, евристична діяльність слідчого базується на таких принципах: розгляд злочину з позицій системно-діяльнісного підходу для виокремлення особливостей криміналістичної характеристики й урахування визначення елементів останньої, які зазнали принципових змін; аналіз практики розслідування злочинів цього виду 3 позицій функціонального підходу з метою виокремлення переліку суб'єктів, які можуть бути залучені до розслідування; аналіз практики розслідування злочинів, які вчинені аналогічним способом чи певною групою злочинців (наприклад рецидивістами), та побудова можливої моделі розвитку злочинної поведінки; вивчення практики розслідування злочинів певної групи з метою доповнення наявної методики додатковим переліком слідчих (розшукових) і негласних слідчих (розшукових) дій, а також судових експертиз, які можуть бути використані; систематизація виявлених практикою недоліків у проведенні слідчих дій за аналогічними злочинами та вироблення організаційно-тактичних рішень із їх усунення.

У випадку відсутності криміналістичної методики розслідування конкретних злочинів із метою їі формування слідчому доцільно послугуватись такими принципами: використання принципу інтеграції слідчої практики, в тому числі й щодо злочинів цієї ж класифікаційної групи, 3 метою формування уявної інформаційної моделі злочинної діяльності (криміналістичної характеристики); використання принципу екстраполяції, зокрема аналітичне опрацювання усталених слідчих ситуацій щодо злочинів цієї категорії та використання розробленої системи тактичних прийомів розв'язання відповідних задач розслідування; використання принципу моделювання, зокрема щодо побудови типових моделей проведення як окремих слідчих (розшукових) і негласних слідчих (розшукових) дій, так і їх комплексів (тактичних операцій).

\section{Список використаних джерел:}

1. Сулейманов Д.І. Концептуальні основи використання інформації при розкритті злочинів : автореф. дис. ... доктора юрид. наук : спец. 12.00.09 «Кримінальний процес та криміналістика; судова експертиза». Київ, 1997. 45 с.

2. Криминалистика социалистических стран / под ред. В.Я. Колдина. Москва : Юрид. лит., 1986. 512 c.

3. Тіщенко В.В. Теоретичні і практичні основи методики розслідування злочинів : монографія. Одеса : Фенікс, 2007. 260 с.

4. Белкин Р.С. Криминалистика: проблемы сегодняшнего дня. Злободневные вопросы российской криминалистики. Москва : НОРМА-ИНФРА-М, 2001. 240 с.

5. Журавель В.А. Проблеми алгоритмізації та програмування розслідування злочинів. Вісник Академії правових наук України. 2008. № 2. С. 191-199.

6. Еникеев М.И. Юридическая психология : учебник. Москва : НОРМА-ИНФРА. Москва, 2001. 517 c.

7. Сучасний тлумачний словник української мови: 50000 слів / за заг. ред. В.В. Дубічинського. Харків : ШКОЛА, 2006. 832 с. 
8. Ищенко Е.П. Алгоритмизация следственной деятельности: монография. Москва : Юрлитинформ, 2010. 304 с.

9. Ищенко Е.П. Алгоритмизация первоначального этапа расследования пре ступлений : дис. ... доктора. юрид. наук : 12.00.09. Свердловск, 1989. 380 с.

10. Зорин Г.А. Криминалистическая эвристика: учеб. пособие по курсу «Криминалистика» Т. 1. Гродно : Гродненский госуд. ун-т, 1994. Т. 1. 210 с.

11. Быховский И.Е. Программирование расследования: возможности и перспективы. Актуальные проблемы советской криминалистики: сб. $\mathrm{cm}$. / Всесоюз. ин-т по изуч. причин и разраб. мер предупр. преступности. Москва, 1980. С. 61-68.

12. Соя-Серко Л.Я. Программирование и творчество в деятельности следователя. Проблемы предварительного следствия в уголовном судопроизводстве : сб. науч. трудов / Всесоюз. ин-т по изучению причин и разработке мер предупреждения преступности. Москва, 1980. C. $32-47$.

13. Аленин Ю.П. Выявление и расследование очагов преступлений: теория и практика : монография. Одесса : Юрид. ин-т ОГУ, 1996. 267 с.

14. Зорин Г.А. Криминалистическая методология. Минск : Амалфея, 2000. 608 с.

15. Философский энциклопедический словарь / редкол. С.С. Аверинцев [и др.]. 2-е изд. Москва : Сов. энциклопедия, 1989. 815 с.

16. Грановский Г Л. Эвристические начала в деятельности експерта. Криминалистика и судебная экспертиза: р яеспубл. межвед. науч. и науч.-метод. сб. Киев, 1973. Вып. 10. C. $165-171$.

17. Соя-Серко Л.А. Программирование расследования. Сочиалистическая законность. 1980. № 1. C. $50-51$.

18. Шаталов А.С. Криминалистические алгоритмы и программы. Теория. Проблемы. Прикладные аспекты. Москва : Лига-Разум, 2000. 250 с.

19. Синчук О.В. Підходи до побудови програми початкового етапу розслідування вбивств із розчленуванням трупа. Теорія та практика судової експертизи і криміналістики. 2011. Вип. 11. C. $161-167$.

20. Возгрин И.А. Криминалистическая методика расследования преступлений. Минск : Высш. школа, 1983. 215 с.

21. Сучасний тлумачний словник української мови: 50000 слів /за заг. ред. В.В. Дубічинського. Харків : ШКОЛА, 2006. 832 с.

22. Философский энциклопедический словарь / редкол.: Л.Ф. Ильичев, П.Н. Федосеев, С.М. Ковалев [и др.]. 2-е изд. Москва : Сов. энциклопедия, 1983. 840 с.

23. Шаталов А.С. Понятие криминалистической алгоритмизации и программирования расследования преступлений. С. 35 .

24. Густов Г.А. Проблемы программирования расследования пре ступлений. Проблемы программирования, организачии и информационного обеспечения предварительного следствия : межвуз. науч. сб. Уфа : Изд-во Башкир. гос. ун-та, 1989. С. 16-27.

25. Асташкина Е.Н. Криминалистические алгоритмы в расследовании квартирних краж : учеб пособие. Москва : Юрлитинформ, 2003. 112 с. 